\title{
Obraz życia politycznego w Jugosławii w ujęciu polskiej emigracji politycznej w Wielkiej Brytanii - kluczowe zagadnienia (1945-1948)
}

\begin{abstract}
Abstrakt: W artykule czytelnik odnajdzie poglądy emigracyjnych ekspertów z kręgów rządu RP na obczyźnie oraz publicystów i dziennikarzy prasy polskojęzycznej wydawanej na Wyspach Brytyjskich na temat czterech kluczowych wydarzeń politycznych z dziejów Jugosławii w latach 1945-1948: spór o Triest, wybory parlamentarne w 1945 r., dwa procesy pokazowe gen. Dragoljuba (Dražy) Mihailovicia i abpa Alojzije Stepinaca oraz konflikt jugosłowiańsko-sowiecki o dominację na Bałkanach.
\end{abstract}

Słow a kluczowe: Alojzije Stepinac, Dragoljub Mihailović, Josip Broz-Tito, Komunistyczna Partia Jugosławii, Jugosławia, Kościół katolicki, Związek Sowiecki, proces pokazowy, Triest.

Abstract: The article presents opinions of emigration experts from the circles of the Polish government-in-exile as well as journalists and commentators of the Polish-language press published in Great Britain about four momentous political events in the history of Yugoslavia in 1945-1948: (1) Trieste crisis, parliamentary election in 1945, two show trials of Gen. Dragoljub (Draža) Mihailović and archbishop Aloysius Viktor Stepinac, and the Yugoslav-Soviet conflict over domination in the Balkans.

Keywords: Aloysius Stepinac, Dragoljub (Draža) Mihailović, Josip Broz Tito, Communist Party of Yugoslavia, Yugoslavia, Catholic Church, Soviet Union, show trial, Trieste.

Władze RP na obczyźnie oraz dziennikarze polskich czasopism ukazujacych się na Wyspach Brytyjskich z nieustającym i wnikliwym zainteresowaniem obserwowali wydarzenia społeczno-polityczne, gospodarcze, kulturalne 
i sportowe w Jugosławii na przełomie wojny i pokoju oraz po zakończeniu działań zbrojnych. Powód był czytelny. W latach wojny w Londynie prowadził działalność emigracyjny rząd jugosłowiański, z którym władze RP utrzymywały dobre, sojusznicze relacje. Polacy ponadto wnikliwie przyglądali się powojennym wydarzeniom na Bałkanach z uwagi na sowieckie zainteresowanie tym regionem. Nie było więc dziełem przypadku to, że porównywali sytuację w powojennej Polsce z Jugosławią i polityką Kremla wobec Belgradu. Dość tu tylko przywołać problemy zbrodni komunistycznych (np. zbrodnia na masowa skalę w Bleiburgu, nie mniej niż 26 tys., a być może nawet 70 tys. ofiar), rozwijającego się $\mathrm{w}$ zawrotnym tempie systemu więziennictwa (np. obóz śmierci w Sremskiej Mitrovicy oraz słynny Goli Otok, który powstał w 1948 r.) oraz drastycznej walki z opozycja, której liderem był gen. Dragoljub (Draža) Mihailović. Nie zabrakło również rozważań na temat jugosłowiańskiego dyktatora Josipa Broz-Tity, którego propaganda komunistyczna wykreowała na męża stanu równego Józefowi Stalinowi (kult jednostki). Oprócz tego nie mniejsza uwage polskiej emigracji przyciagały aspiracje Jugosławii do roli regionalnego mocarstwa, które dały się już zauważyć w 1945 r. Sprawa zaś dotyczyła Triestu i jego przyszłości. Z kilkunastu szczegółowych spraw przedmiotem rozważań były wybory parlamentarne, które odbyły się w listopadzie 1945 r. Termin i przebieg wyborów dał Polakom w Londynie wiele do myślenia oraz celne ustalenia na temat tego, co w niedalekiej przyszłości może wydarzyć się w kraju już kontrolowanym przez Związek Sowiecki. Analizie, aczkolwiek w mniejszym zakresie, były również poddawane sprawy gospodarcze (np. kolektywizacja), kulturalne i sportowe w latach 1945-1948. W okresie, w którym Jugosławia utrzymywała w miarę dobre relacje ze Związiem Sowieckim, nie licząc kilku konfliktów, np. wywołanych zbrodniami Armii Czerwonej po wkroczeniu do Jugosławii oraz brakiem zdecydowanego poparcia Kremla przy próbie opanowania Triestu.

\section{Konflikt o Triest}

Wojna w Europie ponoć dobiegła końca 8 V 1945 r. Jest zrozumiałe, że powyższe stwierdzenie dotyczy walki z Niemcami, którzy skapitulowali przed aliantami: Anglikami, Amerykanami, Sowietami oraz oczywiście i Polakami. Niestety nie stanowiło to kresu walk zbrojnych w kilku regionach Europy, głównie Europy Środkowo-Wschodniej i na Bałkanach. Z Sowietami w obronie niepodległości walczyli m.in. „leśni” na Litwie oraz druga konspiracja w Polsce na terenie prawie całego kraju. Polacy i Czesi spierali się np. o Kotlinę Kłodzka, z udziałem sił zbrojnych. Aspiracje do Siedmiogrodu zgłaszali Węgrzy i Rumuni. Niesnaski pomiędzy sąsiadami: Węgrami i Słowakami wywoływały tereny przygraniczne. Niespokojnie było również na południu Starego 
Kontynentu. Bodajże największe zagrożenie dla pokoju w skali europejskiej wywołał konflikt o Triest ${ }^{1}$.

Jako pierwsza do spornego miasta wkroczyła jugosłowiańska komunistyczna partyzantka późna nocą w ostatnim dniu kwietnia. Pośpiech nie był przypadkowy. Josip Broz-Tito wydając rozkaz zajęcia Triestu i Gorycji, zamierzał wyprzedzić wojska alianckie. Ponadto zachęcał do większej aktywności militarnej dowództwo Armii Czerwonej na terytorium Jugosławii i Austrii. W sukurs jugosłowiańskiemu dyktatorowi przyszli także komuniści włoscy. Ich lider Palmiro Togliatti wydał nawet apel do robotników, aby pomagali oddziałom komunistycznym. 2 V 1945 r. do miasta dotarli pierwsi żołnierze alianccy - dywizja nowozelandzka gen. Bernarda Freyberga ${ }^{2}$. Marszałek Broz-Tito wkroczenie do Triestu tych żołnierzy przyją z oburzeniem. Stwierdził nawet, że alianci, jego byli sojusznicy z koalicji antyniemieckiej, nie uzyskali od niego pozwolenia na zajęcie tego ważnego portu. Argumentował dalej, iż decyzja była bezpodstawna, gdyż Niemcy już opuścili miasto i cała akcja nowozelandzka nie miała sensu. Stanowisko jugosłowiańskiego dyktatora wprawdzie nie było chybione, jeśli chodzi o kolejność w dotarciu do Triestu zainteresowanych stron konfliktu. Niemniej pomylił się w ocenie strategicznej sytuacji. Po pierwsze, alianci zajęli miasto jako ważny dla nich punkt tranzytowy i zaopatrzenia. Po drugie, i to chyba najważniejsze, Anglosasi uznali, że nie muszą konsultować z jugosłowiańskim dyktatorem swoich decyzji militarnych.

Reakcja komunistów jugosłowiańskich była natychmiastowa. Wzmocnili w Trieście swoje siły, które dodatkowo zajęły m.in. Fiume (Rijekę). Dopuściły się również zbrojnych akcji represyjnych wobec ludności cywilnej, głównie Włochów (w kilku publikacjach prasowych czytamy na ten temat: „Doszło wówczas do krwawych starć, w których Jugosłowianie strzelali do tłumu manifestującego swą radość z okazji wyzwolenia miasta, który składał się głównie z Włochów...” czy też: „[...] w dniu 4 maja bojówki komunistyczne uzbrojone w broń palna i sztaby żelazne, zaatakowały bez żadnego powodu pochody młodzieży szkolnej, inwalidów i kombatantów, manifestujących za przynależnością Triestu do Włoch. 150 ofiar i rannych pociagnęło «natychmiastowe reagowanie» komunistów. Osoby, które występowały w obronie bestialsko bitej młodzieży, same naraziły się na podobne potraktowanie”3). Konflikt był już nieunikniony. Rozpoczęła się walka propagandowa, w której uczestniczyły

\footnotetext{
1 T. Wituch, Spór o Triest - wczesny epizod „zimnej wojny”, „Dzieje Najnowsze” 1997, nr 2, s. 73-86; M. Pasztor, Spór o Triest $w$ relacjach dyplomatycznych polsko-wtoskich $w$ latach 1945-1947, „Kwartalnik Historyczny” 2014, nr 2, s. 319-343; P. Żurek, Stowenia pod rzadami Tity (1945-1980). W cieniu Jugostawii, Kraków 2017, s. 26-40.

${ }_{2}^{2}$ P. Żurek, Stowenia pod rzadami Tity..., s. 28.

${ }^{3}$ Tito nie dostanie Triestu, „Dziennik Polski i Dziennik Żołnierza”, 15 V 1945, nr 113, s. 4; M. Janiszewski, Triest, „Orzeł Biały”, 13 V 1945, nr 19, s. 11.
} 
mocarstwa zachodnie oraz Jugosławia i Włochy. Milczenie w sprawie zaś zachował początkowo Józef Stalin. Każda ze stron zgłaszała konkretne postulaty. To one były przedmiotem opinii kolportowanych przez środki masowego przekazu w Europie, w tym m.in. przez polskie kręgi emigracyjne w Wielkiej Brytanii. 11 V 1945 r. Politicus na łamach „Dziennika Polskiego i Dziennika Żołnierza” celnie zauważył, że „Triest nie będzie łatwym orzechem do zgryzienia”. Komentator najpopularniejszego dziennika polskiego na Wyspach Brytyjskich zastanawiał się, czy Tito działał z własnej inicjatywy, czy uzyskał pozwolenie. Jeżeli działał z pozwoleniem, to z czyim? Dalej skonstatował: „,...] Tito nie działał z własnej nieprzymuszonej woli, gdy zgłosił swoje żądania co do Triestu. Jak przebiega linia demarkacyjna w Istrji i Gorycji jeszcze nie wiadomo. Ale targi będą zapewne uparte. Granice włoskie będą niewątpliwie przedmiotem sporu"4. Konkluzja dotycząca długotrwałego sporu okazała się jak najbardziej słuszna. Dziennikarze w „polskim Londynie” wskazywali na kilka podmiotów zainteresowanych spornym terenem. Jest zrozumiałe, że nie tylko Jugosłowianie i Anglosasi uczestniczyli w tym konflikcie i dyskursie. Sprawa nabrała również rozgłosu we Włoszech. Warto wszakże podkreślić, że włoska scena polityczna i opinia publiczna były w tej sprawie podzielone. Najkrócej rzecz ujmując, komuniści (organ prasowy „Unita”) stanęli po stronie Tity, socjaliści (organ prasowy „Avanti”) zaś kontestowali agresję Jugosławii na sporne tereny. W emigracyjnych komentarzach pojawiły się różnego rodzaju argumenty. Jeśli chodzi o wątek włoski, to za najważniejsze należy uznać stwierdzenie, iż stanowisko socjalistów było zgodne $\mathrm{z}$,życzeniami większości narodu włoskiego". Dalej jeden z ekspertów przywołał przełomowa wypowiedź ministra spraw zagranicznych Alcide De Gasperiego, który rzeczowo i stanowczo uzasadnił prawa włoskie do Triestu. Zdaniem publicysty to właśnie ta wypowiedź zjednoczyła, oprócz komunistów, całe społeczeństwo włoskie wokół sprawy Triestu. „Już na drugi dzień «Unita» organ włoskiej partii komunistycznej, zamieścił artykuł zwalczający ostro stanowisko rządu, nawołując jednocześnie społeczeństwo do zachowania czujności i trzeźwości sądu wobec usiłowań propagandy «reakcyjno-faszystowskiej»"s. Reakcja społeczeństwa, zdaniem Michała Janiszewskiego, była łatwa do przewidzenia. W całym kraju rozpoczęły się demonstracje ludności za przynależnością Istrii i Triestu do Włoch. Jednocześnie w wyjątkowo niezręcznej sytuacji znaleźli się włoscy komuniści. Tym bardziej, jak zauważył publicysta, lider komunistów Togliatti zajął w sprawie „mętne stanowisko” - „To nie zależy ode mnie [...] Trzeba żądać rachunku od Mussoliniego"6.

Sprawa Triestu, która rozpoczęła się w 1945 r., była obecna w polityce krajów komunistycznych jeszcze w latach pięćdziesiątych. W 1950 i 1954 r.

\footnotetext{
${ }^{4}$ Politicus, Linia demarkacyjna, „Dziennik Polski i Dziennik Żołnierza”, 11 V 1945, nr 110, s. 2.

${ }^{5}$ M. Janiszewski, op. cit., s. 11.

${ }^{6}$ Ibidem.
} 
organizatorzy Wyścigu Pokoju celowo zaprosili do udziału drużynę Triestu (złożoną ze sportowców z klubów robotniczych), pominęli zaś reprezentacje Włoch i Jugosławii. Co do tego, że był to udział wyłacznie propagandowy, nie mam najmniejszych wątpliwości. Kolarze z Triestu przyjechali na imprezę bez sprzętu, który otrzymali od organizatorów ${ }^{7}$. W 1954 r. na start wyścigu dotarł natomiast jeden kolarz w towarzystwie trzech działaczy. W sprawozdaniu z zawodów jeden z działaczy Głównego Komitetu Kultury Fizycznej, Tomasz Lempart podkreślił: „Pod względem sportowym kolarz ten był słaby. Przyjechał z bardzo słabym sprzętem. Start Triestu ze względów politycznych jest bardzo wskazany".

W emigracyjnych analizach dotyczacych wydarzeń nad Adriatykiem ważne miejsce zajmowała ocena ówczesnego stanowiska mocarstw zachodnich. Anonimowy autor artykułów w „Dzienniku Polskim i Dzienniku Żołnierza” zauważył, iż w sprawie Triestu rząd Wielkiej Brytanii mówi tym samym głosem co władze USA. Mocarstwa podkreśliły, iż Tito stosuje na spornym regionie „politykę faktów dokonanych”, która nie zyskała akceptacji Londynu i Waszyngtonu. Następnie zaznaczył, iż dostrzega w tym problemie dwa istotne aspekty: polityczny i wojskowy. Jeśli chodzi o pierwszy, to nadmienił, że „jest rzeczą niedopuszczalna, by Jugosławia mogła jednostronnie rozstrzygać spory terytorialne, w których jest jedną ze stron". W drugiej kwestii natomiast podkreślił, że Triest jest niezbędny dla zaopatrzenia wojsk alianckich ${ }^{9}$. Tę sama argumentację redakcja wzmocniła w kolejnym artykule. „Zarówno Londyn, jak i Waszyngton podkreśliły, że problem Triestu ma charakter precedensu. Oba rządy alianckie nie mają zamiaru tolerować polityki faktów dokonanych" ${ }^{10}$. Publicyści dziennika w kolejnych tekstach na temat spornego miasta powracali do tego samego wątku: „przypuszczać należy, że stanowczość zachodnich sojuszników [...] przyniesie owoce i że Tito się cofnie. Opinia świata jest wyraźnie niechętna wobec poczynań Tity i jego pobrzękiwania szabelką" Przywołali również celną konstatację z przemówienia premiera brytyjskiego, który stwierdził: „nie po to walczyliśmy, ażeby po klęsce hitleryzmu tworzyły się nowe ośrodki przemocy i systemy policyjne" ${ }^{12}$.

Obok rozbudowanych komentarzy na temat wydarzeń w Trieście, w kilkunastu publikacjach prasowych można zauważyć w tym samym okresie ocenę polityki jugosłowiańskiego dyktatora. Te rozważania zakwalifikowałbym jako niezwykle przydatne do opracowania publicystycznego obrazu Josipa Broz-Tity. Portretu drastycznego i dramatycznego. Bodajże najbardziej krytyczne

\footnotetext{
7 A. Pasko, Wyścig Pokoju $w$ dokumentach władz partyjnych i państwowych 1948-1989, Kraków 2009, s. 64.

8 Ibidem, s. 140.

9 Tito nie dostanie Triestu..., s. 4.

${ }_{10}$ Tito musi opuścić Triest, „Dziennik Polski i Dziennik Żołnierza”, 16 V 1945, nr 114, s. 1.

11 Politicus, Triest $i$ inne sprawy, „Dziennik Polski i Dziennik Żołnierza”, 17 V 1945, nr 115, s. 2.

12 Ibidem.
} 
opinie pomieścił Politicus w „Dzienniku Polskim i Dzienniku Żołnierza”. Na bazie wydarzeń w Trieście oraz drastycznych represji wobec opozycji skupionej wokół gen. Mihailovicia skonstatował, że Tito w swoich poczynaniach zapatrzył się na „ulubione chwyty Hitlera” oraz w „rządach wewnętrznych utrzymuje najgorsze tradycje gestapo, obozów koncentracyjnych, usuwanie niewygodnych ludzi" ${ }^{13}$. Z kolei w innym tekście stanowczo podkreślił, że „metody nieboszczyka Hitlera winny być raz na zawsze usunięte poza nawias międzynarodowych stosunków. Są to metody haniebne i złe, sposoby godne potępienia - bez względu na to, kto je uprawia i stosuje"14. To opinia surowa. Być może byłaby jeszcze bardziej drastyczna, gdyby światło dzienne ujrzały w maju 1945 r. wydarzenia z okolic austriackiego Bleiburga, miejsca zbrodni na masową skalę, której komuniści dokonali na wydanych przez Anglików żołnierzach m.in. z armii gen. Mihailovicia i ich bezbronnych rodzinach. Komunistyczny dygnitarz i bliski współpracownik dyktatora, Milovan Đilas wydarzenia określił „morderczym szałem” ${ }^{15}$. W opinii tej, jak sądzę, nie ma ani jednego słowa przesady:

\begin{abstract}
Najstraszliwszymi aktami tragedii w Bleiburgu były marsze śmierci [...] przeprowadzone później w wielu miastach, miasteczkach i wsiach Słowenii, Chorwacji i Serbii. Dziesiątki tysięcy Chorwatów z rękoma związanymi drutem w typowy rosyjski sposób ustawiono w pewną liczbę kolumn. Następni ci wygłodzeni, spragnieni, wychudzeni, okaleczeni i cierpiacy ludzie zostali zmuszeni do długiego biegu obok swoich „wyzwolicieli”, którzy jechali konno lub wozami. Tych, którzy nie wytrzymali takiego marszobiegu, przebijano bagnetami, bito na śmierć lub rozstrzeliwano, a następnie ciała ich porzucano na poboczu lub w rowie $[\ldots]^{16}$.
\end{abstract}

Natomiast sam dyktator oceniając przebieg zbrodni, po niespełna dwóch tygodniach stwierdził: „Jeśli chodzi o tych zdrajców, którzy znaleźli się w obrębie naszego kraju, poszczególnie dla każdego narodu - to już jest sprawa przeszłości. Ręka sprawiedliwości, ręka zemsty naszego ludu w ogromnej większości już ich dosięgła i tylko jedna ich mała część zbiegła z naszego kraju pod skrzydła protektora"17. O krwawej rozprawie komunistów z opozycja dowiedział się również Stalin. Jeżeli można zawierzyć Đilasowi, to sowiecki dyktator stwierdził: „Tito to zuch. On nie ma problemu z wrogami, wybił ich wszystkich" 18 .

${ }^{13}$ Politicus, Ukrywanie prawdy, „Dziennik Polski i Dziennik Żołnierza”, 24 V 1945, nr 121, s. 2. Por. też: Metody Tito podobne do metod Hitlera, „Dziennik Polski i Dziennik Żołnierza”, 21-22 V 1945, nr 118-119, s. 1.

${ }^{14}$ Politicus, Triest $i$ inne sprawy..., s. 2.

15 M.J. Zacharias, Komunizm, federacja, nacjonalizmy. System władzy w Jugostawii 1943-1991. Powstanie - przekształcenia - rozkład, Warszawa 2004, s. 69. Por. też: P. Żurek, Stowenia pod rzadami Tity..., s. 40-44.

${ }^{16}$ M.J. Zacharias, op. cit., s. 69.

${ }^{17}$ Cyt. za: P. Żurek, Stowenia pod rzadami Tity..., s. 42.

18 Ibidem. 
W dokumentacji rządu RP na obczyźnie na temat represji komunistycznych można jedynie odszukać informację z notatki S. Kleczkowskiego, że ok. dwudziestotysięczny korpus jugosłowiański - nota bene praktycznie bez uzbrojenia, który znalazł się na terenie brytyjskiej strefy okupacyjnej Niemiec - był skazany na bliżej nieokreślone „skompromitowanie”"19. Ówczesne, bezwzględne i zbrodnicze zachowanie partyzantów z komunistycznej proweniencji nie było przypadkowe. Zdaniem emigracyjnych specjalistów „partyzanci Tity (ok. 60 tys. żołnierzy, w kwietniu 1945 r.) rekrutowali się w $20 \%$ z komunistów jugosłowiańskich i obcych, gors zaś stanowiły najbardziej różnorodny element, jak awanturnicy, przestępcy, dezerterzy z armii obcych, wreszcie miejscowa ludność, werbowana często przy pomocy drastycznych metod (palenie wsi, niszczenie wsi)" ${ }^{20}$.

O jeszcze jednej praktyce związanej z działalnością jugosłowiańskiego dyktatora wspominali emigracyjni eksperci. Sprawa dotyczyła deprecjonowania pomocy zachodnich sojuszników dla wojsk komunistycznych w latach wojny. Emigracyjni eksperci wskazali, że wojska komunistyczne, które były w latach wojny zaopatrywane w sprzęt wojskowy wyłącznie przez Anglosasów, po rozpoczęciu kryzysu o Triest celowo zapomniały o tej pomocy. Mało tego, próbowały ją ukryć. Samochody i inny sprzęt wojskowy z wyraźnymi symbolami amerykańskimi lub brytyjskimi były celowo zamalowywane. Żołnierze Tity zaś rozgłaszali, że pomoc otrzymali od innego sojusznika. W tym wypadku wskazywali na Związek Sowiecki.

W konkluzji czytelna wydaje się opinia, iż Tito był postrzegany przez środowiska emigracyjne jako człowiek prosty. Przypisywano mu rolę polityka mało jeszcze wyrobionego. Jeden z publicystów „Dziennika Polskiego i Dziennika Żołnierza” zauważył: „Nie wydaje się jednak, ażeby był on na tyle politycznie dojrzały, aby rozumiał odcienie zachodniej delikatności i subtelna grę kompromisu oraz to, co język angielski ujmuje $\mathrm{w}$ formule give and take (dawać i brać). Marszałek Tito uznaje raczej druga część tej formuły" ${ }^{21}$. W innych opiniach można odszukać informacje, że niczym Stalin mieszkał w pałacu należącym do króla i był ,ze wszech stron otoczony tajnymi agentami i policja" ${ }^{22}$. Nie bez znaczenia wydaja się przy charakterystyce Tity krótkie, aczkolwiek precyzyjne i nader dosadne, opinie na temat jego najbliższych współpracowników z lat wojny. Moša Pijade to sympatyczny Żyd jugosłowiański i przy okazji zdolny malarz impresjonista, bystry i cięty publicysta, bywalec paryskich knajp i kompan Ilii Erenburga. Vladimir Ribnikar posiadał najwspanialszy na Bałkanach tor automobilowy oraz słynął z tego, że adorował

\footnotetext{
${ }^{19}$ Instytut Polski i Muzeum Sikorskiego (dalej: IPMS), A 11E/1173, Notatka S. Kleczkowskiego dla ministra A. Tarnowskiego z 11 VII 1946 r.

${ }^{20}$ IPMS, Kol. 138/228, Jugosłowiańskie siły zbrojne, k. 3.

${ }_{21}$ Stuszne stanowisko, „Dziennik Polski i Dziennik Żołnierza”, 16 V 1945, nr 114, s. 2.

${ }^{22}$ IPMS, A 11E/1173, Notatka S. Kleczkowskiego dla ministra A. Tarnowskiego...
} 
najpiękniejsze kobiety. Poza tym był właścicielem ważnego belgradzkiego dziennika „Politika”. W „polskim Londynie” przypisywano mu numer dwa. Tuż za nim był Božidar Magovac, „smutny zawsze, ni to dziennikarz, ni to nauczyciel". Obok nich zostali ulokowani adwokat chorwacki dr Ivan Ribar, popularny rzeźbiarz chorwacki Antun Augustinčić oraz „cichy, niepozorny starszy pan o sympatycznej twarzy myśliciela”, Dymitr Włakow. Dalej w hierarchii znaleźli się: dr Josip Smodlaka, były poseł w Madrycie i Watykanie, smakosz najdroższych szampanów, Vladimir Zacevec, który był nie tylko „eks księdzem prawosławnym i eks treserem fok w cyrku", ale wcześniej oficerem czetników u gen. Dragoljuba Mihailovicia. Grono to uzupełniali: płk Sulejman Filipović, muzułmanin z Bośni, dr Dušan Saranec, eksgubernator królewski i bliżej nieznany Rade Pribićević, wnuk Adama Pribićevicia, wybitnego serbskiego pisarza i polityka z przełomu XIX i XX stulecia ${ }^{23}$. Jak wskazał emigracyjny ekspert, wymienieni powyżej sympatyczni artyści, znudzeni sybaryci, ckliwi intelektualiści stanowili przykrywkę dla głównych współpracowników dyktatora, odpowiadajacych za powojenne represje w Jugosławii oraz przygotowanie służb specjalnych do wyborów parlamentarnych. Na tej niechlubnej liście zostali umieszczeni m.in. Aleksandar Ranković, „szara eminencja sztabu generalnego, żelazną ręką porządkujacy szeregi wojska”, Stanko Škare - długoletni przyjaciel Bolesława Bieruta z Kominternu, Ljubo Ilić - pułkownik brygad międzynarodowych w Hiszpanii oraz Lew Gočniak, wcześniej najbardziej ruchliwy łącznik Kominternu na Bałkanach, potem szef kontrwywiadu w armii Tity. Tę grupe dopełniali wspomniany już Dymitr Włakow i France Frol. W konkluzji Władysław Popławski stwierdził, że to „cała plejada ludzi, o których nic albo bardzo niewiele słyszy się na zewnątrz, którzy z reguły nie udzielają wywiadów prasowych, mają wstręt do aparatów fotograficznych, w Belgradzie nie chodza na «drinki» do brytyjskich czy amerykańskich oficerów”. To oni wykonali cała „brudną robotę” przed wyborami parlamentarnymi ${ }^{24}$.

\section{Wybory w 1945 r. sprawdzianem demokracji za żelazną kurtyną}

Na problem Jugosławii emigracyjni specjaliści patrzyli przez pryzmat działalności dwóch podmiotów politycznych - obozu skupionego wokół króla Piotra oraz komunisty Josipa Broz-Tity. Ten ostatni i jego sprzymierzeńcy mogli liczyć, zdaniem analityków z „polskiego Londynu”, na poparcie nie więcej niż

\footnotetext{
${ }^{23}$ W. Popławski, Tło „wyborów” w Jugostawii, „Orzeł Biały”, 26 XI 1945, nr 47, s. 5. Warto tu tylko zauważyć, że wymieniony przez autora artykułu A. Augustinčić był m.in. twórca zwycięskiego projektu pomnika J. Piłsudskiego w Katowicach (wspólnie z D. Guliciem) w 1937 r., na co Popławski nie zwrócił uwagi.

${ }^{24}$ Ibidem, s. 8.
} 
5\% społeczeństwa. To w zasadniczy sposób wpłynęło na taktykę działania Komunistycznej Partii Jugosławii (KPJ).

Przedmiotem sporu, jak ogłosili eksperci emigracyjni, były przede wszystkim wybory parlamentarne. Chodziło w tym wypadku o zasadniczą kwestię, czy wyborcy zagłosują na jedna, czy kilka list wyborczych. Ministrowie z byłego jugosłowiańskiego rządu emigracyjnego, Milan Grol i dr Ivan Šubašić z tego też powodu opuścili gabinet koalicyjny, w którego składzie byli również licznie reprezentowani komuniści. W argumentacji zaś podali, że „nie moga wyrazić zgody na proponowane przez reżim titowski wybory monopartyjne"25. Titę potępiły również niektóre ugrupowania chorwackie, w tym partia kierowana przez dr. Vladimira Mačka. W tym samym duchu wypowiadało się duchowieństwo uznające „reżim titowski za szkodliwy i niechrześcijański” ${ }^{26}$.

Zastanawiając się nad sytuacja polityczną w Jugosławii, analitycy emigracyjni zauważyli, że król Piotr popełnił kilka brzemiennych w skutkach błędów. Przede wszystkim pod dymisji Šubašicia i Grola powinien niezwłocznie powołać do życia nowy gabinet złożony głównie z prokrólewskich polityków. Jeśliby nie mógł tego osiagnać, to ekspert z Ministerstwa Spraw Zagranicznych (MSZ) sugerował, że król powinien zablokować wybory parlamentarne. Niestety, nie skorzystał z tej możliwości.

Sprawa wydawała się niezwykle istotna, gdyż trudno było przewidzieć wynik wyborów. Wybory parlamentarne na Węgrzech, które odbyły się wcześniej (4 XI 1945 r.), przyniosły niespodziewany wręcz sukces prozachodniej Niezależnej Partii Drobnych Rolników, która uzyskała 57\% głosów (pewni sukcesu komuniści zdobyli tylko $17 \%$ ). W tym wypadku na nic zdała się obecność Sowietów na Węgrzech. Sytuacja w Jugosławii była jednak bardziej skomplikowana. Komuniści dopuścili się szeregu zbrodni, nawet na masowa skalę. Szantażowali wręcz całe społeczeństwo. Manipulowali przy tym ordynacją i samym procesem wyborczym.

Wybory odbyły się 11 XI 1945 r. Jak zauważyli specjaliści z MSZ, „celem sparaliżowania bojkotu stronnictw opozycyjnych, Tito zarządził głosowanie za i przeciw liście rządowej. Z góry było wiadomo, jaki będzie rezultat wyborów, w których silnie rozbudowany aparat policji i milicji politycznej był głównym reżyserem" ${ }^{27}$. W tym celu w lokalach wyborczych wystawiono dwie urny, jedna na głosy popierające reżim komunistyczny, druga dla opozycji. Jest zrozumiałe, na co zwrócili uwagę specjaliści z „polskiego Londynu”, że każdy wyborca, który zamierzał głosować przeciwko Ticie, musiał się wykazać nie lada odwaga, ponieważ w lokalach wyborczych specjalnie oddelegowani obserwatorzy śledzili kroki wszystkich głosujących. Nie mniej charakterystycznym posunięciem reżimu była decyzja, że każdy, którego nazwisko figuruje

\footnotetext{
${ }^{25}$ IPMS, A 11E/1173, Jugosławia. Notatka dla prezydenta RP z 12 XI 1945 r., k. 1.

${ }^{26}$ Ibidem.

${ }^{27}$ IPMS, Kol. 138/228, Jugosłowiańskie siły..., k. 38.
} 
w rejestrze wyborczym, a powstrzyma się od głosowania, będzie uważany za aprobującego listę rządową. W organie prasowym komunistów tak zostało wytłumaczone owo rozwiązanie: „Nowość ta przeszkodzi tym, którzy chcieliby wypaczyć demokratyczny charakter wyborów. Jest to najlepsza odpowiedź dla tych, którzy za jedną drogę uważają powstrzymanie się od głosu. Z punktu widzenia prawa ci, którzy nie głosują wyrażają zgodę na wybranych kandydatów”28. Potwierdził to również czołowy działacz komunistyczny Moša Pijade, który skonstatował, że opozycja będzie mogła zaliczyć do swoich zwolenników tylko tych, którzy wrzuca głosy do urny wyborczej, oczywiście tej drugiej. Ekspert z polskich kręgów emigracyjnych powyższą opinię celnie ocenił, że zabieg komunistów w zasadzie rozstrzygną już wynik wyborów. „[...] jest rzeczą oczywista, że w systemie terroru, jaki istnieje w Jugosławii, jedyna praktycznie możliwą formą opozycji jest demonstracyjne powstrzymanie się od głosu. Jest to bez porównania łatwiejsze, aniżeli udanie się do biura wyborczego i rzucenie głosu do specjalnej skrzynki opozycyjnej”29.

Dzień przed wyborami niezawodny w sprawach Jugosławii komentator ukrywajacy się pod pseudonimem Politicus dodał do już znanych argumentów kolejne. Zwrócił uwagę na wyrobienie polityczne elektoratu, np. w porównaniu z wyborcami na Węgrzech.

Tito i jego jaczejki grają oczywiście na o wiele słabszym wyrobieniu politycznym chłopa chorwackiego i serbskiego. W Chorwacji pozbyto się dr Maczka, który był tem dla Chorwacji, czem Witos dla Polski, toteż manewry są ułatwione. W Serbii dokonano tak olbrzymich spustoszeń, takiego zastraszenia mas, iż szala wyborów przychylona będzie zapewne na stronę „frontu narodowego". Przez odebranie prawa głosowania tysiącom ludzi. Przez sterroryzowanie jeszcze liczniejszych tysięcy Tito spodziewa się zwycięstwa. W istocie wolnych wyborach Tito - nawet przy wyniszczeniu kraju - poniósłby klęskę ${ }^{30}$.

W dokumentach innej proweniencji wskazano na kolejny, niepowtarzalny w dziejach całej Europy „argument wyborczy” wzmacniajaccy pozycję obozu Tity. Rzecz dotyczyła dopuszczenia do wyborów, na mocy wcześniej przygotowanej ordynacji, nawet nieletnich partyzantów Tity biorących udział w wojnie przeciwko Niemcom. Podsumowując wyniki wyborów, w polskojęzycznych emigracyjnych publikacjach podpierano się m.in. oświadczeniem króla Piotra II. Monarcha zaś zauważył:

wyniki ostatnio odbytych wyborów nie mogą dalej nikogo w najmniejszej mierze przekonać o tym, że wola Narodu [...] została swobodnie wyrażona. Świat zna już dobrze metody Frontu Narodowego wyolbrzymianie cyfr mające wykazać jego popularność.

\footnotetext{
${ }^{28}$ Komedia „wyborów” w Jugosławii, „Dziennik Polski i Dziennik Żołnierza”, 10 XI 1945, nr 267, s. 4.

${ }^{29}$ Ibidem.

${ }^{30}$ Politicus, Lekcja wegierska, „Dziennik Polski i Dziennik Żołnierza”, 10 XI 1945, nr 267, s. 2.
} 
Jest rzeczą powszechnie znaną [...], że znaczne odłamy ludności usunięto z miejsca zamieszkania i pozbawiono możności swobodnego głosowania ${ }^{31}$.

Kolejnym ważnym wydarzeniem, stanowiącym konsekwencję wyborów parlamentarnych w listopadzie 1945 r., któremu polska emigracja poświęciła więcej uwagi, była zmiana ustroju kraju z monarchii na republikę. W tym wypadku rząd RP na obczyźnie ponownie przywołał oświadczenie króla Piotra II. Monarcha zaś podkreślił, że zmiana nastapiła z pogwałceniem konstytucji i tradycji Jugosławii. Winnym uznano marszałka Titę, który „odebrał prawo decyzji w tej sprawie Narodowi” ${ }^{2}$. Detronizację rodziny Karađorđeviciów i ogłoszenie Jugosławii republika potraktowano w „polskim Londynie” jako całkowite włączenie kraju południowych Słowian w orbitę wpływów Związku Sowieckiego.

Specjaliści emigracyjni zajmujący się tematyką bałkańską prognozowali, że rządy komunistyczne w Jugosławii nie będą krótkotrwałe. Owa konstatacja wynikała z taktyki działania charakterystycznej zreszta nie tylko dla KPJ. Jej myśla przewodnią był tzw. demokratyczny centralizm. Jeden z publicystów „Dziennika Polskiego i Dziennika Żołnierza” podkreślił, że polega on na tym, iż „skoro raz proklamowano, że centrala rządząca wyraża interesy ludu i wyłoniona została $\mathrm{z}$ jakiś tam wyborów, np. wyborów w centralnym komitecie, wtedy może ona rządzić i całą organizacją partyjną i całym krajem"33. Od 1944 i 1945 r. podobna taktykę stosowały również i inne partie komunistyczne w krajach za żelazną kurtyną.

\section{Procesy gen. Dragoljuba Mihailovicia i abpa Alojzije Stepinaca}

Publikacje prasowe w „polskim Londynie” zawierały szczegółowe dane i informacje na temat biografii gen. Dragoljuba Mihailovicia, jego działalności wojskowej w latach II wojny światowej oraz postawy po zakończeniu działań wojennych ${ }^{34}$. Zainteresowanie jugosłowiańskim generałem nie było dziełem przypadku. Zreszta z kilku powodów. Generał Mihailović w latach wojny był sojusznikiem Anglosasów, w związku z tym i rządu RP. W jego oddziałach służyli Polacy i zyskali wyjątkowo przychylne opinie ${ }^{35}$. W końcu po wojnie był

${ }^{31}$ IPMS, A 11E/1173, Jugosławia. Oświadczenie króla Piotra II.

32 Ibidem.

${ }^{33}$ Er., Kraj uczciwej opozycji, „Dziennik Polski i Dziennik Żołnierza”, 24 IX 1946, nr 225, s. 2.

${ }^{34}$ Problem gen. Dragoljuba Mihailovicia w ujęciu polskich środowisk emigracyjnych był już przedmiotem szczegółowych rozważań. Zob. J. Lencznarowicz, Jatta. W kręgu mitów założycielskich polskiej emigracji politycznej 1944-1956, Kraków 2009, s. 227-236; T. Wolsza, Proces generała Dragoljuba Mihailovicia $w$ świetle polskiej publicystyki emigracyjnej (1946 r.), w: Polska i Jugosławia w stosunkach międzynarodowych po II wojnie światowej, red. M. Pavlović, A. Zaćmiński, Bydgoszcz 2014, s. 195-202.

${ }^{35}$ P. Żurek, Polacy w oddziałach czetników Dražy Mihailovicia, „Przegląd Wojskowo-Historyczny" 2018, nr 3-4, s. 143-158. 
wrogo nastawiony do reżimu komunistycznego, partyzantki Josipa Broz-Tity i Związu Sowieckiego. Ostatecznie za to zapłacił najwyższą cenę. Własne życie. Wydaje się, iż najbardziej czytelną ocenę wydarzeń w Jugosławii, w tym analizę rywalizacji pomiędzy obozem skupionym wokół Tity i gen. Mihailovicia, pomieścił autor cennego dokumentu pt. Jugostowiańskie sity zbrojne z $1946 \mathrm{r}$. Genezy wydarzeń z okresu powojennego doszukiwał się w latach wojny:

w ciagu lat 1941-1945 Michajlowicz i Tito stali się głównymi postaciami wydarzeń tak w samej Jugosławii, jak też i na Bałkanach. Obaj wyrośli do znaczenia symbolów pewnych celów ideowo-politycznych i społecznych, o które toczyła się miniona wojna. Ich walka z Niemcami i Włochami, jak i wzajemna bratobójcza walka stanowiły główne tło wydarzeń. Mimo to jednak, decydujący wpływ na sytuację jak również na ostateczny rezultat wywarła rozgrywka na linii Londyn-Waszyngton-Moskwa ${ }^{36}$.

Jest też zrozumiałe, że za Titem stała Moskwa, za generałem zaś Wielka Brytania i później USA. To właśnie Kreml w latach wojny zwrócił się z prośbą do gen. Mihailovicia, który był ministrem wojny w rządzie emigracyjnym Jugosławii, o udzielenie pomocy komunistom jugosłowiańskim. Prośba początkowo zyskała jego aprobatę. Dopiero w listopadzie 1941 r., kiedy Sowieci skierowali do Jugosławii „zdolnego i energicznego, lecz nieznanego szerzej agenta Kominternu Josipa Broz Tito", sytuacja wewnętrzna w Jugosławii uległa zmianie $^{37}$. Na dodatek partyzantka komunistyczna aktywnie uczestnicząca w walkach z Niemcami uzyskała duże wsparcie od anglosaskich sojuszników. Jak zauważył autor dokumentu, Tito nabrał wówczas pewności, że może rozpoczać otwartą i bezkompromisową walkę z gen. Mihailoviciem. Ponadto komunistom sprzyjały i inne okoliczności. Brytyjczycy i Amerykanie doprowadzili w lipcu 1944 r. do kompromisu pomiędzy rządem emigracyjnym Jugosławii Ivana Šubašicia, który rezydował na Wyspach Brytyjskich, i komunistami w Jugosławii. Konsekwencje stanowiła m.in. dymisja gen. Mihailovicia ze stanowiska ministra wojny, którym był od 14 I 1942 r. Kolejne wydarzenia pogorszyły sytuację generała i jego obozu politycznego. Po spotkaniu Josipa Broz-Tity z premierem rządu emigracyjnego w Rzymie w sierpniu 1944 r., nota bene w obecności Winstona Churchilla, Ivan Šubašić wyjechał do Moskwy. Następnie w styczniu 1945 r. definitywnie wypowiedział posłuszeństwo królowi Piotrowi i udał się do Jugosławii. W marcu 1945 r. był już członkiem rządu komunistycznego pod prezesurą Tity. Zresztą niedługo. We wrześniu 1945 r., na dwa miesiace przed wyborami parlamentarnymi, jugosłowiański dyktator wydał polecenie zaaresztowania byłego premiera rządu emigracyjnego ${ }^{38}$. Był to czytelny sygnał, jakie intencje przyświecały Ticie i jego mocodawcom ze Związku Sowieckiego. Rozszyfrowany także przez Mihailovicia. Obserwujący

\footnotetext{
${ }^{36}$ IPMS, Kol. 138/228, Jugosłowiańskie siły zbrojne..., k. 1.

${ }^{37}$ Ibidem.

${ }^{38}$ Ibidem, k. 3.
} 
z oddali wydarzenia gen. Władysław Anders, który nie krył swojej sympatii do jugosłowiańskiego generała, zauważył:

w miarę posuwania się wojsk sowieckich na zachód coraz ciszej zaczynało być o bohaterskim Michajloviću, a coraz głośniej wypływało nazwisko znanego agenta Kominternu - Tity. Mniej więcej od marca 1944 r. Wielka Brytania przerzuciła się całkowicie na stronę Tity, a w misji wojskowej do niego znalazł się nieprzypadkowo syn premiera Churchilla, Randolph, co polegało prawdopodobnie na złudzeniu, że zdoła on utrzymać wpływy brytyjskie przeciw rosyjskim ${ }^{39}$.

Autorzy emigracyjnych publikacji prasowych wskazywali, że po $1945 \mathrm{r}$. gen. Dragoljub Mihailović znalazł się w sytuacji bez wyjścia i prowadził nadal działalność partyzancką oraz niepodległościową w terenie górzystym, w którym się potem ukrywał. Kolejna część informacji odnosiła się do przebiegu procesu oraz powściagliwości Anglosasów w udzieleniu pomocy aresztowanemu generałowi, który w latach 1941-1945 był sojusznikiem Londynu, Waszyngtonu oraz Moskwy, po agresji Niemiec na Zwiazzek Sowiecki. Sytuacja generała przypominała tę, w jakiej znaleźli się m.in. przywódcy Polskiego Państwa Podziemnego (PPP) i dowódcy Armii Krajowej (AK), np. Leopold Okulicki „Niedźwiadek”, zwłaszcza w kontekście procesu moskiewskiego. Największe zainteresowanie tą sprawą wykazywały: „Dziennik Polski i Dziennik Żołnierza”, „Orzeł Biały” i „Polska Walcząca” - pisma powiązane z kręgami rządowymi i wojskowymi, w tym z 2 Korpusem, „Wiadomości”, „Nowy Świat”, „Placówka”, „Trybuna” oraz szczególnie zaciekawiony tym faktem „Przegląd Polski” - wydawany przez resort spraw wewnętrznych rządu RP w Londynie. Autorami artykułów byli m.in. Aleksander Bregman, Ryszard Kiersnowski, Józef Łobodowski, Stefan Mękarski, Jan Nowak (Jeziorański), Zygmunt Nowakowski, Stanisław Stroński, Stanisław Strzetelski, Zygmunt Szempliński (ps. Stanisław Klinga), Kazimierz Zamorski i Melchior Wańkowicz ${ }^{40}$. Ze strony władz RP problematyką jugosłowiańską zajmował się urzędnik MSZ S. Kleczkowski, w późniejszym okresie rzecznik prasowy prezydenta Augusta Zaleskiego.

Publicyści polskiej prasy emigracyjnej zwracali uwage przede wszystkim na rolę, jaka alianci przypisywali jugosłowiańskiemu generałowi w latach wojny. Przypominali, że w 1942 r. amerykańscy i brytyjscy mężowie stanu składali mu hołd za bohaterską i bezkompromisowa postawę w walce z Niemcami: „Z podziwem śledzimy prowadzone przez Pana operacje, które oddaja nieocenione usługi sprawie sojuszniczej" ${ }^{41}$. Wymowa tej wypowiedzi byłaby wszakże niepełna, gdybyśmy pominęli jej dalszą część nawiąującą do zachowania Mihailovicia w 1941 r. Otóż dziennikarz słusznie podkreślił, że generał

\footnotetext{
${ }^{39}$ W. Anders, Bez ostatniego rozdziału. Wspomnienia z lat 1939-1946, Lublin MCMXCII, s. 418.

${ }^{40}$ Najpełniejszą listę dziennikarzy zajmujących się tytułowym problemem pomieścił Jan Lencznarowicz (op. cit.).

${ }^{41}$ St.M., Michajłowicz, „Dziennik Polski i Dziennik Żołnierza”, 22 VII 1946, nr 170, s. 2.
} 
przygotowywał struktury powstańcze przeciwko Niemcom jeszcze w tym okresie, gdy najlepszym sojusznikiem Adolfa Hitlera był Józef Stalin, czyli od wiosny $1941 \mathrm{r}$. Pisał dosadnie w tej kwestii, że Mihailović spiskował przeciwko Niemcom, „gdy Mołotow toastował [...] na cześć Ribbentropa”" ${ }^{42}$. Mało tego, wedle opinii publicystów to tylko dzięki jego postawie wobec Niemców agresja III Rzeszy na Związek Sowiecki została opóźniona o kilka tygodni. „Jugosławia postanowiła się bić. Sprawił to Draża Michajłowicz. Jugosławia biła się przez parę tygodni, lecz i tego wystarczyło, aby ofensywę na Rosję Sowiecka opóźnić o dwa miesiące, oraz aby armia niemiecka znalazła się u bram Moskwy nie w październiku ale w grudniu, co uratowało państwo sowieckie od klęski”"33. Emigracyjni eksperci i dziennikarze nie dawali również wiary argumentom brytyjskim, które później podchwyciła propaganda komunistyczna, że gen. Mihailović po początkowych partyzanckich walkach z Niemcami zaniechał tej działalności i skupił swoją uwagę na niszczeniu konkurencji, czyli oddziałów Tity. W tej kwestii Bregman konstatował:

[...] taktyka Michajłowicza była uzasadniona. Wstrzymywał się on z działaniami na większą skalę do chwili, gdy nastapiłaby inwazja anglo-amerykańska. Gdyby inwazja ta została podjęta, jak tego zresztą sam Churchill pragną, to pomoc ze strony oddziałów Michajłowicza, działających na tyłach armii niemieckiej, byłaby nieoceniona. Z chwilą natomiast gdy Anglosasi wyrzekli się planów ataku na Bałkany, Michajłowicz miał wszelkie powody po temu, by nie marnować swych sił. Również zupełnie słusznie stał on na stanowisku, że niebezpieczeństwo grożące krajowi ze strony Tity jest również wielkie, co niebezpieczeństwo ze strony okupanta ${ }^{44}$.

Wątek ten kontynuował Szempliński, który podkreślił, że zaniechanie walki było próbą „oszczędzania swemu narodowi nadmiernego upustu krwi”. Dalej natomiast zaznaczył, że to samo robili Amerykanie i Brytyjczycy. „Rozważania na temat, kto pomagał więcej, Tito czy Michajłowicz są bez znaczenia - Benesz pomagał najmniej, a nie stoi przed sądem. Bór-Komorowski zaś jest oskarżony o to, że za dużo pomagał. Michajłowicz walczył przeciw komunizmowi - to jest przyczyna jedyna" ${ }^{45}$. Przedstawiciele polskiej prasy emigracyjnej dali więc stanowczy odpór sugestiom na temat kolaboracji generała z Niemcami, pojawiającym się w propagandzie powojennej w Jugosławii oraz w innych krajach za żelazna kurtyną.

Gros emigracyjnych publikacji i ekspertyz przyniosło sporo danych i informacji na temat samego procesu, w którym obok generała było oskarżonych 23 jego podwładnych oraz wysokich urzędników jugosłowiańskich władz

\footnotetext{
${ }^{42}$ Ibidem.

${ }^{43}$ Nagroda za wielkość. Rozstrzelanie gen. Draży Michajłowicza, „Przegląd Polski” 1946, nr 2, s. 12 .

${ }^{44}$ A.B. (A. Bregman), Proces Michajłowicza, „Dziennik Polski i Dziennik Żołnierza”, 11 VI 1946, nr 135, s. 2.

${ }^{45}$ S. Klinga, Sprawa Michajłowicza, „Polska Walcząca”, 27 VII 1946, nr 30, s. 1.
} 
emigracyjnych, m.in. premierzy Slobodan Jovanović i Božidar Purić. Dziesięciu spośród oskarżonych sądzono zaocznie. Jak podkreślili dziennikarze, śledztwo było prowadzone pod skrupulatnym nadzorem Edvarda Kardelja. Dragoljub Mihailović został poddany okrutnym torturom, które trwały 72 godziny, po czym na pół żywemu dano do podpisania zeznania, z ostrzeżeniem, że tortury będą powtórzone w wypadku, jeśli w czasie procesu wycofa cokolwiek z tego „zeznania”46. Został również na krótki czas przetransportowany do Moskwy, zaś następnie z powrotem do Belgradu. Jak można przypuszczać, Sowieci zadecydowali, że rozprawa przeciwko generałowi odbędzie się na terytorium Jugosławii. Nie powtórzyli scenariusza z 1945 r., gdy przed sądem w Moskwie postawili 16 Polaków, czołowych polityków i wojskowych PPP. Ze względu na stan zdrowia pierwszego więźnia Jugosławii, gdyż przez pewien czas istniało poważne niebezpieczeństwo śmierci generała $\mathrm{z}$ uwagi na silne zatrucie organizmu, proces został początkowo przesunięty z 6 na 19 V 1946 r., zaś później aż do 10 VI 1946 r.

Przesunięcie terminu procesu $\mathrm{z}$ majowego na czerwcowy wprowadzało do dyskursu międzynarodowego dodatkowy, ważny argument polityczny, którego geneza sięgała lat wojny. Proces rozpoczął się dwa dni po londyńskiej paradzie zwycięstwa (8 VI 1946 r.), w której nie tylko nie uczestniczyli żołnierze Polskich Sił Zbrojnych na Zachodzie, ale jeden z ważniejszych sojuszników Anglosasów był sądzony przez innego sojusznika - komunistycznego, który aspirował do władzy dyktatorskiej w Jugosławii. Na ten aspekt wydarzenia zwrócił uwagę Nowakowski na łamach „Orła Białego”, nie po raz pierwszy w swojej działalności publicystycznej biorąc w obronę skrzywdzonych Polaków oraz bohaterskiego generała ${ }^{47}$. Jan Lencznarowicz oceniając artykuł bezkompromisowego publicysty, skonstatował za nim, że „[...] wódz czetników wyraża zasady, które zwycięża, to on żyć będzie w chwale, gdy powróci wolność. Jego zabójcy zaś i ci, którzy na morderstwo to pozwolili, przemina z fala barbarzyństwa zalewającą teraz Europę"48. Powyższa prognoza okazała się celna po ponad pół wieku, ale tylko dla obszaru Europy Środkowo-Wschodniej. Anglosasi, którzy zachowali w tej konkretnej sprawie całkowitą bierność, nie ponieśli żadnych konsekwencji.

Bezstronni obserwatorzy - świadkowie procesu - zauważyli, że oskarżony Mihailović był w wyjątkowo złej kondycji, wręcz wyczerpany. Sam z trudem śledził przebieg wydarzeń. W sytuacji, gdy składał wyjaśnienia inne od wcześniej ustalonych, w procesie po prostu ogłaszano przerwę. Potem generał powracał na salę i już bez przeszkód potwierdzał zarzuty oskarżycieli. Wańkowicz podał, że ci, co widzieli generała w sądzie, twierdzili, iż to nie ten sam człowiek. Niekiedy przypominał lunatyka ${ }^{49}$. Jak można wnosić, był

\footnotetext{
${ }^{46}$ IPMS, A 11E/1173, Proces gen. Mihailovicia, 3 VII 1946 r.

${ }_{47}$ Z. Nowakowski, Małoduszne $i$ godne pogardy, „Orzeł Biały”, 7 VII 1946, nr 27, s. 4.

48 J. Lencznarowicz, op. cit., s. 235.

${ }^{49}$ M. Wańkowicz, Mord na gen. Michajłowiczu, „Orzeł Biały”, 11 VIII 1946, nr 32, s. 2.
} 
pod wpływem środków farmakologicznych lub narkotyków. Trzy lata później postępowanie jugosłowiańskich śledczych skopiowali Węgrzy, którzy w identyczny sposób przygotowali do pokazowej rozprawy sądowej prymasa kard. Józsefa Mindszentyego ${ }^{50}$.

Generałowi Dragoljubowi Mihailoviciowi zarzucono utworzenie w latach okupacji niemieckiej jugosłowiańskiej „Armii Krajowej”, przy pomocy której zamierzał storpedować działalność „narodowo-wyzwoleńczą narodów jugosłowiańskich”. Dalej akt oskarżenia wskazywał na współpracę generała z jugosłowiańskim Quislingiem - gen. Milanem Nediciem oraz z niemieckimi i włoskimi wojskami okupacyjnymi. Wszystko to, jak podkreślił prokurator, działo się za zgodą rządu emigracyjnego w Londynie ${ }^{51}$. Emigracyjni dziennikarze bez wyjątku zarzuty dotyczące kolaboracji gen. Mihailovicia z okupantami uznali za bezpodstawne, wręcz wyssane z palca. Szukali natomiast analogii do wydarzeń w Polsce i losów 16 przywódców PPP. Tytuł jednego z cytowanych artykułów - „Belgrad” oskarża - jest nader czytelny. Zamorski nie bez racji argumentował, że przed jugosłowiański sąd generała postawili Sowieci, tak jak wcześniej uczynili to z przedstawicielami PPP, których osądzili w Moskwie. Dodał do tego, iż polską AK zestawiali na równi z jugosłowiańska „Armia Krajowa”. Obie armie obwiniali o kolaborację z okupantami i niszczenie partyzantki komunistycznej. Rząd RP w Londynie połączyli z jugosłowiańskim rządem emigracyjnym, którym również zarzucali współpracę z Niemcami. Prokurator wskazywał ponadto na winę Brytyjczyków, którzy tolerowali na swoim terytorium działalność rządów emigracyjnych i nie potrafili $\mathrm{w}$ pore zahamować ich antykomunistycznej i antysowieckiej polityki. W Jugosławii jej ostrze było ponoć wymierzone przede wszystkim przeciwko Josipowi Broz-Ticie i jego partyzantom ${ }^{52}$. Jeśli chodzi natomiast o losy gen. Dragoljuba Mihailovicia, to zdaniem polskich emigracyjnych dziennikarzy niczym nie różniły się one od losów gen. Leopolda Okulickiego „Niedźwiadka”, ostatniego komendanta AK, który po procesie szesnastu już nigdy nie wrócił do Polski. Za swoją działalność niepodległościową zapłacił życiem.

Zdaniem polskich specjalistów z emigracyjnego MSZ los Mihailovicia był przesądzony już przed rozpoczęciem procesu. W całym kraju komuniści zorganizowali wiele wieców i spotkań ze społeczeństwem, na których zostały „zdemaskowane zbrodnie generała i lud domagał się przykładnego ukarania największego zbrodniarza i wroga narodu"53. Jednocześnie Tito oświadczył publicznie, że zbrodnie Mihailovicia zostały udowodnione, zaś minister bezpieczeństwa, komunista Ranković dodał, że oskarżony przyznał się do

\footnotetext{
${ }^{50}$ T. Wolsza, Za żelazna kurtyna. Europa Środkowo-Wschodnia, Zwiazek Sowiecki $i$ Józef Stalin $w$ opiniach polskiej emigracji politycznej $w$ Wielkiej Brytanii 1944/1945-1953, Warszawa 2005, s. 213-215.

${ }^{51}$ K. Zamorski, „Belgrad” oskarża, „Orzeł Biały”, 23 VI 1948, nr 25, s. 4.

${ }^{52}$ Ibidem.

${ }^{53}$ IPMS, A 11E/1173, Proces gen. Mihailovica, 3 VII 1946 r.
} 
zarzucanych mu zbrodni. Do generała władze jugosłowiańskie nie dopuściły adwokatów amerykańskich oraz bezstronnych świadków, oficerów amerykańskich i brytyjskich. W podobnym duchu sprawę relacjonował Bregman na łamach „Dziennika Polskiego i Dziennika Żołnierza”. Wybitny emigracyjny publicysta zauważył, że wyrok na generała oczywiście zapadł z góry. Jego zdaniem przebieg procesu potwierdził upadek cywilizacji i demokracji, które zostały w Jugosławii zdeptane, przy bierności Zachodu.

Trzeba nieprawdopodobnej naiwności - konstatował - by oczekiwać, że w kraju takim jak Jugosławia istnieje wymiar sprawiedliwości w rozumieniu świata zachodniego. Jugosławia dzisiejsza ze wszystkich krajów strefy sowieckiej jest najbardziej zaawansowana na drodze do kompletnej sowietyzacji. Sprawiedliwość jugosłowiańska nie będzie się niczym różniła od sprawiedliwości sowieckiej, która tak dobrze znamy choćby z procesu 16 -tu ${ }^{54}$.

Jak podkreślił jeden z emigracyjnych ekspertów, celem procesu belgradzkiego było nie tylko skazanie Mihailovicia. Chodziło jeszcze o dwie inne sprawy. Po pierwsze, o wykazanie, że Mihailović i reprezentowany przez niego obóz patriotyczno-królewski nigdy nie prowadzili szerszej walki przeciwko Niemcom. Po drugie, komuniści chcieli stworzyć choćby pozory, że jedynie Zwiazek Sowiecki prowadził bezkompromisową i zdecydowaną walkę z Niemcami ${ }^{55}$. Jako żywo argumenty te przypominają sytuację w powojennej Polsce, gdy Polska Partia Robotnicza wyłącznie sobie przypisywała skuteczna walkę z okupantem oraz odmawiała prawa do legalnej działalności rządowi $\mathrm{RP}$ w Londynie jako władzy skompromitowanej współpraca z Niemcami. $\mathrm{W}$ innym dokumencie wskazano natomiast, że proces Mihailovicia był typowym procesem pokazowym. Miał skompromitować wszystkich tych, którzy znaleźli się z różnych powodów poza rządem Josipa Broz-Tity. Autor konkluzji myślał tu o królu Piotrze II i jego najbliższych współpracownikach z lat II wojny światowej ${ }^{56}$. Podobieństwo do powojennych dziejów 2 Korpusu było tu również bardzo czytelne. Przebieg procesu obserwowała również opozycja demokratyczna w Polsce, byli działacze PPP. Stefan Korboński zanotował 16 VII 1946 r.: „ogłoszono dzisiaj, że przywódca podziemia jugosłowiańskiego, generał Michajłowicz, został skazany w Belgradzie na śmierć. Wiadomość ta zrobiła wielkie wrażenie i dała dużo do myślenia. Taki los spotyka obecnie przywódców antyniemieckiego podziemia [...]"

Polska prasa emigracyjna po zakończeniu procesu nadal śledziła wydarzenia w Jugosławii. Stąd już dzień po zamordowaniu generała podała informację o jego śmierci 17 VII 1946 r. W „Przeglądzie Polskim” gen. Dragoljuba Mihailovicia oceniono jako człowieka uosabiającego prawdę, zamierzającego

\footnotetext{
${ }^{54}$ A.B. (A. Bregman), op. cit., s. 2.

${ }^{55}$ IPMS, A 11E/1173, Proces gen. Mihailovica, 3 VII 1946 r.

${ }^{56}$ Ibidem, Notatka S. Kleczkowskiego dla ministra A. Tarnowskiego...

57 S. Korboński, W imieniu Kremla, Warszawa 2017, s. 152.
} 
uratować ludzkość przed zbliżającą się katastrofą ${ }^{58}$. „Dziennik Polski i Dziennik Żołnierza" konstatował:

Zamordowany został kilka dni temu przez komunistów gen. Draża Michajłowicz - cieszy się natomiast dotychczas życiem p. Ribbentrop, dramatis persona najdziwaczniejszego w dziejach, chociaż nikogo dziś już właściwie nie interesującego procesu norymberskiego. Gdy zaś do tych paradoksów dodamy, że zamordowanie rzekomego „kolaboracjonisty” Michałjowicza następuje w chwili startu Moskwy do wyścigu o zjednanie sobie Niemców, w chwili, w której wczorajsi naziści, a dzisiejsi koncesjonowani socjaliści niemieccy w rosyjskiej strefie okupacyjnej wiwatują na cześć pana Mołotowa, obiecujaccego Niemcom rewindykacje terytorialne na wschodzie - to dopełnia się upiorny obraz krzywd i zagłady jakichkolwiek zasad moralnych $[\ldots]^{59}$.

Wańkowicz po egzekucji napisał: „17 lipca Michajłowicza rozstrzelano. Jak psa, bez świadków. I nie wiadomo, gdzie jego grób”60. Była to czytelna aluzja odnosząca się do miejsca pochówku opozycyjnych polityków i żołnierzy wyklętych zamordowanych przez komunistów, przy wydatnej sowieckiej pomocy, w powojennej Polsce.

W publikacjach pojawił się ponadto nie mniej istotny watek dotyczacy bierności polityków zachodnich w obliczu procesu generała i jego późniejszej śmierci. Bezkompromisowy wobec Anglosasów Nowakowski zauważył, że wprawdzie mordu dokonali komuniści jugosłowiańscy, to jednak należy się w tym wypadku zastanowić również nad postawa zachodnich dyplomatów, którzy nie dostrzegają tej zbrodni. Za pointę jego rozważań można uznać konstatacje dotyczacą Londynu i Nowego Jorku: „Tu nie słychać strzałów, stąd nie widać szubienic"

W polskich czasopismach emigracyjnych równolegle $\mathrm{z}$ informacjami na temat śmierci generała pojawiły się wzmianki o tragicznych losach żony Dragoljuba Mihailovicia, która w czasie wojny została wywieziona do obozu koncentracyjnego w Auschwitz-Birkenau i tam zmarła. „Przegląd Polski” przywołał w tym wypadku wspomnienia Zofii Kossak ( $Z$ otchtani): „W roku 1943 przywieziona została do lagru Milana Michajłowiczowa, żona byłego generalissimusa jugosłowiańskiego, otaczana wielkim szacunkiem przez swoje rodaczki. [...]. Michajłowiczowa umarła zimą 1944 r., równie opuszczona i sponiewierana, jak zwykłe haeftlingi”. W komentarzu do tegoż wydarzenia i rzekomej kolaboracji generała z Niemcami redakcja zgryźliwie podkreśliła: „Lata 1943 i 1944 to te lata, w których według oskarżeń trybunałów Tity Michajłowicz współpracował z Niemcami. Został za to przykładnie rozstrzelany Dobrze mu tak, nie trzeba było posyłać żony do Oświęcimia na konszachty z Niemcami”62.

\footnotetext{
${ }^{58}$ Nagroda za wielkość..., s. 13.

${ }^{59}$ St.M., op. cit., s. 2.

${ }^{60}$ M. Wańkowicz, op. cit., s. 2.

${ }_{61}$ Z. Nowakowski, Krew na rękach, „Nowy Świat”, 26 VIII 1947, nr 237.

62 Jak Michajłowicz wspótpracowat z Niemcami, „Przegląd Polski” 1946, nr 4, s. 42.
} 
Kolejnym procesem politycznym, który odnotowali emigracyjna prasa i eksperci, była rozprawa przeciwko arcybiskupowi Zagrzebia Alojzije Stepinacowi. Komuniści zaaresztowali go dwukrotnie. Po pierwszym zatrzymaniu w maju 1945 r. został zwolniony po dwóch tygodniach. Następnie doszło do skutku jego spotkanie z Josipem Broz-Titem. „Nie pomogło to załagodzić sporu, jaki istniał między Kościołem katolickim a nową komunistyczną władzą w Jugosławii” ${ }^{63}$. Arcybiskup nadal konsekwentnie krytykował komunistów i ich despotycznego lidera. Los duchownego był więc przesądzony. We wrześniu 1946 r. ścisłe kierownictwo partii (m.in. Josip Broz-Tito, Edvard Kardelj i prokurator Josip Hrnčević) podjęło decyzję o ponownym zatrzymaniu arcybiskupa.

Rangę symbolu proces Stepinaca zyskał z powodu roli i znaczenia Kościoła katolickiego przede wszystkim w Słowenii i Chorwacji. Autor dokumentu pt. Jugostowiańskie sity zbrojne zanotował m.in.:

opozycję w kraju stanowi Kościół katolicki. Chociaż szereg biskupów złożyło deklarację lojalności wobec państwa, masy i ich główni przywódcy katoliccy są nastrojeni zdecydowanie wrogo wobec reżimu. W Chorwacji, Słowenii i Dalmacji kościół popiera bierny opór. Państwo w zamian za wolność religii wymaga absolutnej lojalności, kościół natomiast obstaje przy swoich więzach z Watykanem, posiadłościach ziemskich i wywieraniu wpływu na wychowaniu młodzieży. Zgodnie z nową konstytucja, wpływy kościoła zostały ograniczone w szkołach, Kościół został oddzielony od państwa, a dekret o reformie rolnej ograniczył prawo posiadania wielkich posiadłości kościołowi ${ }^{64}$.

Termin procesu arcybiskupa, wyznaczony na wrzesień i październik 1946 r., nie był dziełem przypadku. Z kilku powodów. Nadal nie rozstrzygnięto definitywnie sporu o Triest pomiędzy Jugosławią i mocarstwami zachodnimi. Ponadto tuż za miedzą w Grecji toczyła się wojna domowa. W końcu nie sposób w tym miejscu pominąc jeszcze jednego wydarzenia. Nieco wcześniej, na wiosnę 1945 r. Alojzije Stepinac wydał list pasterski, w którym była mowa o bezwzględnych prześladowaniach Kościoła katolickiego i księży. Jak można więc przypuszczać, władze komunistyczne Jugosławii zamierzały osłabić międzynarodowa krytykę związana z procesem prymasa Chorwacji lub nawet ukryć przebieg rozprawy, w tym zakamuflować surowy wyrok w gaszczu innych wydarzeń $^{65}$. W procesie arcybiskupa zapadł wyrok długoletniego więzienia (16 lat) ${ }^{66}$. Część wyroku - 5 lat Stepinac odbył w więzieniu w Lepoglavie. Następnie, aż do śmierci w 1960 r., przebywał w areszcie domowym w parafii

\footnotetext{
${ }^{63}$ A. Biernat, Powojenne rozliczenia zbrodni ustaszy popetnionych w czasie II wojny światowej, w: Wina i kara. Społeczeństwa wobec rozliczeń zbrodni popelnionych przez reżimy totalitarne w latach 1939-1956. Studia i materiaty, red. nauk. P. Pleskot, Warszawa 2015, s. 225.

${ }^{64}$ IPMS, 138/228, Jugosłowiańskie siły..., k. 38.

65 T. Wolsza, Za żelazna kurtyna..., s. 212.

${ }^{66} \mathrm{Na}$ temat Alojzije Stepinaca dysponujemy monografia z serbskiej proweniencji: N. Žutić, Nadbiskup Stepinac. Ideologija i polityka 1934-1946, Beograd 2017.
} 
w Krašiciu. Zamiana więzienia na areszt domowy była podyktowana chęcia zmiany polityki władz komunistycznych wobec Stolicy Apostolskiej67. Jeden z emigracyjnych ekspertów na łamach „Przeglądu Polskiego” skonstatował, że „dyktatorom jugosłowiańskim nie chodziło tak bardzo o ukaranie arcybiskupa, jako sojusznika dr [Vladka] Mačka, za tym jako prężnej podpory Chorwackiej Partii Chłopskiej, ile o uderzenie w autorytet Kościoła katolickiego, z którym komuniści prowadzili nieubłaganą walkę, na jaką komuniści w innych krajach pod kontrola sowiecka, jak np. w Polsce i Czechosłowacji, jeszcze się nie odważaja”" ${ }^{8}$. Prasa emigracyjna i biuletyny rządowe przyniosły w końcu informację, że po kolejnych atakach komunistów na duchowieństwo chorwackie Stolica Apostolska obłożyła ekskomuniką wszystkich tych, którzy byli uwikłani w aresztowanie i proces prymasa ${ }^{69}$. W styczniu 1953 r. Stolica Apostolska mianowała kilku nowych kardynałów, w tym m.in. Stepinaca, który jednak z uwagi na uwięzienie nie odebrał kapelusza kardynalskiego ${ }^{70}$. Nominacja wywołała „zmasowaną krytykę w Jugosławii - najpierw medialna, a potem dyplomatyczną" ${ }^{1}$. Nie było więc dziełem przypadku to, iż Tito postanowił zerwać stosunki dyplomatyczne z Watykanem.

Po obu procesach emigracyjni publicyści i eksperci byli zgodni co do tego, że Jugosławia stała się bezwolnym narzędziem w rękach polityki sowieckiej $\mathrm{w}$ jej walce z Zachodem.

\section{Konflikt jugosłowiańsko-sowiecki}

Tematyka jugosłowiańska w szerszym zakresie wróciła do emigracyjnych rozważań w 1948 r. Powód pozornie był czytelny. Sprawa dotyczyła daleko idących ambicji Josipa Broz-Tity, który zamierzał pełnić rolę lidera obozu komunistycznego na Bałkanach. Kierownictwo Kominformu zaapelowało do jugosłowiańskich komunistów o wewnętrzny bunt wobec przywódcy i porzucenie błędnej drogi. Z tego też powodu Józef Stalin podjął decyzję o bezwzględnym ataku propagandowym, na forum całego ruchu komunistycznego, wymierzonym w jugosłowiańskiego przywódcę. Wydaje się wszakże, że władze Związu Sowieckiego postanowiły wykorzystać dyktatora jugosłowiańskiego do misternej gry polegającej na wykreowaniu Tity na wewnętrznego wroga w całym obozie, którym wcześniej był Trocki. Po jego śmierci pojawił się deficyt. Wróg wewnętrzny był od dawna wpisany w taktykę Stalina do mobilizacji oraz

${ }^{67}$ A. Biernat, op. cit., s. 226.

68 T.P. (T. Piszczkowski), Polityka Jugostawii, „Przegląd Polski” 1946, nr 5, s. 66.

${ }_{69}$ A. Pragier, Po obu stronach żelaznej kurtyny, „Sprawy Polskie”, IX 1947, nr 2, s. 6.

${ }^{70}$ J. Żaryn, Stolica Apostolska wobec Polski i Polaków w latach 1944-1958 w świetle materiałów ambasady RP przy Watykanie, Warszawa 1998, s. 211.

${ }^{71}$ P. Wawryszuk, Polityka władz Jugosławii wobec Kościoła katolickiego w latach 1945-1971, „Pamięć i Sprawiedliwość” 2017, nr 1, s. 242. 
szantażowania społeczeństwa w zależności od rozwoju sytuacji. Zresztą już niebawem w kilku krajach za żelazną kurtyną (np. Czechosłowacja, Bułgaria, Węgry, Rumunia, Polska) zostali zaaresztowani i straceni niektórzy liderzy partii komunistycznych. Powodem, dla którego komuniści kolportowali na żądanie Kremla, była ich współpraca z Titem ${ }^{72}$. Można więc skonstatować, że pomysł z wrogiem wewnętrznym nie tylko nie był chybiony, ale też konsekwentnie wykorzystywany przez polityków sowieckich.

29 VI 1948 r. władze Jugosławii odrzuciły wszystkie oskarżenia. Po dwudziestoletniej przerwie odbył się kolejny, V Kongres KPJ, który na sekretarza generalnego wybrał Josipa Broz-Titę. Lider partii w przemówieniu ponownie skrytykował ataki na Jugosławię, ale jednocześnie podkreślił, iż Jugosławię i Związek Sowiecki łączy przyjaźń. Delegaci głosili hasło „Tito - Stalin”. Komuniści jugosłowiańscy przy każdej okazji wspierali inicjatywy sowieckie, np. na forum Organizacji Narodów Zjednoczonych i różnych konferencji międzynarodowych (m.in. dotyczaccych uregulowania nawigacji na Dunaju). Historycy uważaja, iż w relacjach międzynarodowych z innymi państwami bloku sowieckiego Tito grał wówczas na zwłokę. Nie jest wykluczone, że przygotowywał kraj do konfliktu zbrojnego. Ponadto dążył do stopniowego pozyskiwania zwolenników w kraju i za granica ${ }^{73}$. Konsekwencje były zauważalne przede wszystkim w sowieckiej strefie wpływów oraz w samej Jugosławii. Do więzień i obozów (w tym np. do najbardziej znanego na Gołej Wyspie - Goli Otok) zostali wtrąceni ci komuniści jugosłowiańscy, którzy byli zwolennikami

${ }^{72}$ M.J. Zacharias, op. cit., s. 103-104. W emigracyjnych publikacjach pojawił się również zgoła sensacyjny scenariusz wydarzeń z jugosłowiańskim dyktatorem w roli głównej. „Jeszcze w końcu 1947 r. Departament Wojskowy opracował dwa plany opanowania Europy Zachodniej znane pod nazwą plan A i plan B [...]. Plan A przewidywał zajęcie Europy Zachodniej latem 1948 r. przez oddziały Armii Czerwonej. Armie satelickie miały współdziałać z wojskiem rosyjskim [...]. Plan B natomiast, właściwy plan Kominformu przewidywał opanowanie Europy nieco później na jesieni 1948 r. przy pomocy "Armii Proletariackich» zorganizowanej i uruchomionej w krajach Kominformu pod naczelnym dowództwem marszałka Tity. Armia ta miała liczyć (z Grekami i Albańczykami) 1737000 ludzi (podziemna armia komunistyczna we Włoszech 500 tys., podziemna armia komunistyczna we Francji 600 tys.). Armia była pomyślana jako armia ochotnicza [...]. Zwolennicy planu B, na którego czele stał marszałek Tito, byli zdania, że obecny stan i uzbrojenie armii francuskiej i włoskiej nie pozwala na dłuższy i skuteczny opór wobec ofensywy armii proletariackiej. Sądzę, że zatarg Tito - Kominform na tle powyższych informacji i pogłosek [...] dopiero staje we właściwym oświetleniu. Jest jasne, że gdyby w Moskwie zdecydowano się na wybór planu B, to Tito musiałby otrzymać pozory formalnej niezależności od Moskwy [...]. Zerwanie Kominformu z Tito daje mu właśnie takie pozory niezależności i swobody ruchów, za skutki której ani Sowiety, ani organizacje komunistyczne nie będą odpowiedzialne. Znaczy to, że na wypadek akcji Tito w Zachodniej Europie mocarstwa zachodnie nie będą miały bezpośredniego powodu do wypowiedzenia wojny ZSRS, ani też od akcji [...] przeciw piatej kolumnie komunistycznej we własnych krajach [...]”. T. Norwid, Tito: aktor czy marionetka?, „Orzeł Biały”, 21 VIII 1948, nr 34, s. 2.

${ }^{73}$ M.J. Zacharias, op. cit., s. 109-110. 
Związku Sowieckiego i kontestowali przywództwo Josipa Broz-Tity. Ustała wymiana gospodarcza, naukowa, kulturalna i sportowa pomiędzy krajami komunistycznymi. Nagle, np. pod naciskiem Zwiąku Sowieckiego, zostały przedwcześnie zakończone igrzyska bałkańskie. Kilkuset sportowców straciło okazję do międzynarodowej rywalizacji. Tym bardziej że rzadko kiedy wyjeżdżali do zachodniej Europy i byli zdani na rywalizację krajowa. Kraje komunistyczne pod wpływem Związku Sowieckiego zbojkotowały również olimpiadę szachową w Dubrowniku ${ }^{74}$. W propagandzie komunistycznej inspirowanej przez Kreml Titę prezentowano jako agenta amerykańskiego i wroga Związu Sowieckiego. W publicystyce prasowej w krajach za żelazną kurtyna trudno było odszukać o Jugosławii chociażby jedno dobre zdanie.

Jeśli chodzi o emigracyjny dyskurs na temat konfliktu sowiecko-jugosłowiańskiego, to dominowały w nim dwa zagadnienia - polityczne i gospodarcze. Warto również wskazać, że emigracyjni eksperci zastanawiali się nad autentycznością sowieckich zarzutów. Jeden z publicystów „Przeglądu Polskiego” stwierdził, że komunikat z 28 VI 1948 r. był „utrzymany w tonie doktrynalnym, jakim fanatyczna sekta religijna wyklina nie chcących okazać skruchy odstępców". W sprawie zaś zarzutów dodał, że niektóre oskarżenia były nieprawdziwe, inne bez cienia wattpliwości można by zaadresować do pozostałych krajów znajdujących się w sowieckiej strefie wpływów. W szczegółowych sprawach autor Schizmy belgradzkiej zanotował, że sowiecki zarzut, iż komuniści w Jugosławii nie maja przewagi we Froncie Ludowym, jest niesłuszny, gdyż rządzą oni krajem niepodzielnie. Podobnie ocenił pretensje Moskwy w sprawie kolektywizacji wsi jugosłowiańskiej, że komuniści ja zaniedbali. Przywołał w tym wypadku przykłady innych krajów, które w ogóle opierały się kolektywizacji. Można tu tylko wnosić, iż autor miał na myśli przede wszystkim Polskę. Przy kolejnym oskarżeniu o nadmierny terror stwierdził, że zarzut „brzmi groteskowo”75. Oczywiście, jeżeli przyszłoby porównać sprawę z drastycznymi represjami w Związku Sowieckim. W analizie pojawiły się jednak informacje o zarzutach Kominformu, które mają rację bytu. Na pierwszym miejscu wymienił inwigilację agentów sowieckich w Jugosławii, na drugim zaś lekceważące wypowiedzi jugosłowiańskich komunistów o Związku Sowieckim i tamtejszych elitach politycznych. W konkluzji natomiast zauważył: „Tito został potępiony za zbytnią samodzielność, za próbę wyzwolenia się spod opieki sowieckiej i stworzenie w Belgradzie nowego, niezawisłego wobec Moskwy, ośrodka komunizmu"76. W zakresie polityki zagranicznej,

74 T. Wolsza, Polsko-jugostowiańskie kontakty sportowe $w$ dwudziestoleciu międzywojennym $i$ w pierwszych powojennych latach (do 1950 r.). Przyktad sportu szachowego, w: Polska i Jugosławia po II wojnie światowej, red. M. Pavlović, N. Stambolija, A. Zaćmiński, Bydgoszcz 2016, s. 135-137.

75 Schizma belgradzka, „Przegląd Polski” 1948, nr 8, s. 57.

${ }^{76}$ Ibidem, s. 58. 
kontynuował rozważania autor tekstu, Belgrad kontestował agresywne rozwiązania praktykowane przez Wiaczesława Mołotowa.

Przedmiotem analizy była również postawa Jugosławii i wynikające z tego konsekwencje dla całego obozu komunistycznego. Autor artykułu podkreślił, że Tito odrzucił oskarżenia Moskwy jako absurdalne. Dalej zauważył, że przywódca południowych Słowian nie doczekał się jeszcze znaczącej opozycji w kraju i z tej strony nic mu nie grozi. Można wywnioskować, iż ekspert zastanawiał się $\mathrm{w}$ tym momencie nad niebezpieczeństwem piątej kolumny, która mogliby do swoich celów wykorzystać Sowieci.

Kluczowe wydaje się wszakże pytanie dotyczące reakcji Związu Sowieckiego. Nie bez znaczenia wydawały się tu dwa argumenty, na które wskazał analityk z „polskiego Londynu”. Pierwszy odnosił się do zdobycia władzy przez Josipa Broz-Titę bez „bagnetów sowieckich”, przy pomocy Anglosasów. Drugi, nie mniej istotny, wskazywał na fakt, iż Tito, Kardelj i Ranković stworzyli samodzielnie partię komunistyczną i podporządkowany jej aparat ucisku ${ }^{77}$. Autor dał więc do zrozumienia, że Jugosłowianie nie zawdzięczali Sowietom zbyt wiele. Nie mieli wobec nich długu wdzięczności. Te argumenty okazały niezwykle ważne dla dalszej analizy w kontekście zagrożeń dla Jugosławii i jej przywódców. Jeśli chodzi o losy kraju, to pojawiły się trzy scenariusze wydarzeń. Pierwszy, jak zauważyli specjaliści, odnosił się do stworzenia w innych krajach bloku wschodniego ośrodków, w których będą szkoleni emigranci polityczni z Jugosławii, kontestujący władzę Tity, z perspektywa powrotu do Belgradu „na sowieckich czołgach”. Drugi, nie mniej drastyczny, dotyczył zamachu na Josipa Broz-Titę. Trzeci, który miał charakter uniwersalny i był praktycznie do wykorzystania przy pierwszym i drugim scenariuszu, odnosił się do izolowania Jugosławii pod względem gospodarczym wśród państw komunistycznych.

Jeśli chodzi o pierwszy plan działalności, to emigracyjni autorzy stwierdzili, że na pograniczu węgierskim i bułgarskim można było zauważyć koncentrację wojsk. Wątek ten kontynuowano w innej publikacji, w której czytamy: „prasa zagraniczna od pewnego czasu informuje o koncentracji wojsk sowieckich oraz satelickich (węgierskich, rumuńskich i bułgarskich) na pograniczu Jugosławii. Jednocześnie zaostrzają się stosunki pomiędzy Jugosławią oraz jej sasiadami, przy czym na pierwszy plan wysuwa się zatarg z Bułgaria, która znowu zaczyna akcentować swoje zainteresowanie sprawa macedońską"78. Ważniejsza była natomiast uwaga, iż w Czechosłowacji i Rumunii zawiązały się struktury opozycyjne wobec władz w Belgradzie, w których składzie znaleźli się dyplomaci i żołnierze. W „Bukareszcie gromadzą się uciekinierzy wojskowej opozycji i tutaj, w sąsiedztwie Jugosławii, tworzony jest ośrodek bojowy, przygotowywany dla przyszłej próby zamachu"79. Z kolei w Pradze powstało

\footnotetext{
${ }_{77}$ Ibidem.

78 T.P. (T. Piszczkowski), Położenie Jugostawii, „Przegląd Polski” 1948, nr 9, s. 66.

${ }^{79}$ Idem, Jugostawia w walce $z$ „Kominformem”, „Przegląd Polski” 1948, nr 11, s. 35.
} 
pismo „Nowa Borba”, w którym stanowisko redaktora obją były ambasador Jugosławii w Bukareszcie, Golubović. Wybór stolicy Czechosłowacji nie był dziełem przypadku. Studiowało tam sporo Jugosłowian. Agitacja zatem dotyczyła młodego pokolenia ${ }^{80}$. Warto w końcu przytoczyć opinię, w której można by odszukać syntetyczną ocenę ówczesnej sytuacji. Dla emigracyjnych ekspertów Tito cieszył się poparciem nie tylko komunistów, ale i środowisk antykomunistycznych, które reżim dyktatora uważały za lepszy niż okupację sowiecka. Nie sposób też pominać w tym miejscu oceny dotyczącej siły armii jugosłowiańskiej w 1949 r. Była nie tylko największa na Bałkanach (700 tys. żołnierzy), ale i bezdyskusyjnie oddana i wierna marszałkowi ${ }^{81}$.

Jeśli chodzi natomiast o prognozy związane z losem jugosłowiańskiego dyktatora, to pojawiły się opinie, że w Moskwie zapadł już na niego wyrok śmierci. „Heretykom się nie przebacza” ${ }^{2}$ - pisał jeden z ekspertów.

Trzeci scenariusz dotyczył izolacji gospodarczej Jugosławii na arenie międzynarodowej. Josip Broz-Tito dając odpór agresywnej polityce Związku Sowieckiego, na forum jugosłowiańskiego Zgromadzenia Narodowego stwierdził pod koniec grudnia 1948 r., że państwa komunistyczne znajdujące się pod kontrolą Moskwy oraz sam Związek Sowiecki zamierzały uczynić z Jugosławii kraj kolonialny. Daż̇yły do utrzymania Jugosławii na niskim poziomie uprzemysłowienia, wykorzystując jej surowce do własnych celów ${ }^{83}$. Wśród emigracyjnych ekspertów pojawiła się również opinia, że Rada Wzajemnej Pomocy Gospodarczej (RWPG) została pomyślana jako organizacja, która miała na celu „poddanie całego handlu zagranicznego” państw bloku komunistycznego kontroli sowieckiej. Co więcej, „Komekon”, emigracyjne określenie RWPG, postawił sobie za cel „izolacje gospodarczą Jugosławii”84. W poszczególnych artykułach prasowych można odszukać informacje, które państwa i w jakim zakresie uczestniczyły w owej blokadzie. Polska ograniczyła dostawy węgla. Eksport surowców (np. ropy naftowej) wstrzymały również Albania i Rumunia. W bojkocie ekonomicznym uczestniczyły ponadto Bułgaria i Węgry. Wedle emigracyjnych opinii

rząd jugosłowiański radzi sobie jak może, korzystając z drobnych na razie dawek pomocy ze strony mocarstw zachodnich, z którymi unika jednak jakichkolwiek wiążących zobowiązań. Ostrożność ta płynie częściowo ze zrozumiałych wątpliwości, czy na wypadek konfliktu zbrojnego z Rosją mógłby reżim jugosłowiański spodziewać się bardziej wydatnej pomocy niż ta, jakiej Zachód udzielił Polsce przeciw Niemcom w r. $1939^{85}$.

\footnotetext{
${ }^{80}$ Ibidem.

${ }^{81}$ IPMS, A 11E/871, List ambasadora Zawadowskiego do ministra Sokołowskiego z 9 VII 1949 r.

${ }^{82}$ Schizma belgradzka..., s. 59.

${ }^{83}$ Tito oskarża Rosję $i$ satelitów o bojkot gospodarczy Jugosławii, „Dziennik Polski i Dziennik Żołnierza”, 29 XII 1948, nr 309, s. 1.

${ }^{84}$ Komekon, „Przegląd Polski” 1949, nr 3, s. 39.

85 T.P. (T. Piszczkowski), Położenie Jugostawii..., s. 66.
} 
Obok powyższego stwierdzenia pojawiło się jeszcze inne, nie mniej istotne z punktu widzenia relacji Zachód - Wschód i miejsca w tym układzie Jugosławii. „Blokada od wschodu mogłaby rzucić Titę w ramiona mocarstw zachodnich" ${ }^{86}$. Jak zauważyli emigracyjni specjaliści, byłoby to wyjątkowo niekorzystne rozwiązanie dla Związku Sowieckiego. Wynika z tego, że skonfliktowane strony Moskwa i Belgrad nie zdecydują się na siłowe rozwiązanie problemu.

Po konflikcie Tity ze Stalinem minister Mieczysław Sokołowski podsumował wydarzenia następująco: „sprawa odstępstwa dyktatora jugosłowiańskiego wymaga uregulowania już to z powodu nadziei, które budzi ona na Zachodzie, oraz szkodliwego wpływu na pojedynczych działaczy komunistycznych w krajach satelickich" ${ }^{87}$. Przy czym minister nieco dalej zauważył, iż do samych czystek w krajach za żelazną kurtyną wszyscy się już przyzwyczaili i nie stanowią one żadnego zagrożenia. Inny zaś obserwator wydarzeń na Bałkanach skonstatował, że „rozłam Tity z Moskwą nie nastapił na tle różnic doktrynalnych i nie zmierzał do przywrócenia Jugosławii choćby pozorów demokracji. Toczył się wyłącznie na gruncie zagadnienia, czy Jugosławia ma rządzić Tito, czy Moskwa"88. Historyk Marian S. Wolański analizując politykę jugosłowiańskiego dyktatora, przede wszystkim zaś jej znaczenie dla spójności imperium sowieckiego, doszedł do wniosku, że polska emigracja odebrała „bunt Tity” jako sygnał dla Anglosasów, że na monolicie bloku wschodniego dała się zauważyć poważna rysa ${ }^{89}$. Ów konflikt dla niektórych polskich ekspertów rokował pewne nadzieje na rozbicie bloku sowieckiego od wewnątrz. Nie wszyscy wszakże w „polskim Londynie” oceniali w ten właśnie sposób wydarzenia w Jugosławii. Katastroficznych dla Związku Sowieckiego prognoz nie podzielili m.in. redaktorzy „Przeglądu Polskiego”, czasopisma związanego z Ministerstwem Spraw Wewnętrznych rządu RP na obczyźnie.

\section{Streszczenie}

Polskie kręgi emigracyjne na Wyspach Brytyjskich z dużym zainteresowaniem obserwowały wydarzenia na Bałkanach. Jest też zrozumiałe, że zwróciły uwagę przede wszystkim na sytuację w Jugosławii. Po zakończeniu wojny była ona najważniejszym państwem w regionie, w którym ścierały się interesy lokalnych komunistów, przy wsparciu Związku Sowieckiego oraz obozu demokratycznego, identyfikowanego z władzami jugosłowiańskimi na obczyźnie oraz gen. Dragoljubem Mihailoviciem. W latach 1945-1948 do głównych zagadnień, które

${ }^{86}$ Schizma belgradzka..., s. 59.

${ }^{87}$ IPMS, A 48/Z III/8, Exposé kierownika ministerstwa ministra Mieczysława Sokołowskiego wygłoszone na plenum Rady Narodowej w dniu 29 VI 1949 r., k. 5.

88 A. Pragier, Puszka Pandory, Londyn 1969, s. 180.

${ }^{89}$ M.S. Wolański, Europa Środkowo-Wschodnia w myśli politycznej emigracji polskiej $w$ latach 1945-1975, Wrocław 1996, s. 81-82. 
zyskały rangę wiodących, zarówno w ocenie rządu RP na obczyźnie, jak i w publicystyce emigracyjnej, zostały zaliczone międzynarodowy konflikt o Triest, sfałszowane wybory parlamentarne w 1945 r., procesy pokazowe gen. Dragoljuba Mihailovicia i abpa Alojzije Stepinaca oraz poważny spór pomiędzy Belgradem i Moskwa, zakończony wykluczeniem Jugosławii z Kominternu.

\section{A Picture of Political Life in Yugoslavia through the Eyes of Polish Political Emigration in Great Britain - the Key Issues (1945-1948)}

Polish emigration circles in Great Britain observed the developments in the Balkans with great interest. It is understandable that they paid attention mainly to the situation in Yugoslavia, after the end of the world the most important state in the region where different interests of local communists were in conflict, with the assistance of the Soviet Union and democratic camp identified with the Yugoslavian government-in-exile and Gen. Dragoljub (Draža) Mihailović. In 1945-1948, the key issues, both in the opinion of the Polish government-in-exile, and of the emigration press included: the international conflict over Trieste, fixed parliamentary elections in 1945, show trials of Gen. Dragoljub (Draža) Mihailović and archbishop Aloysius Viktor Stepinac, and the grave Yugoslav-Soviet controversy between Belgrade and Moscow over the domination in the Balkans which ended with the exclusion of Yugoslavia from the Comintern.

\section{Bibliografia}

Biernat A., Powojenne rozliczenia zbrodni ustaszy popetnionych w czasie II wojny światowej, w: Wina i kara. Społeczeństwa wobec rozliczeń zbrodni popetnionych przez reżimy totalitarne $w$ latach 1939-1956. Studia i materiaty, red. nauk. P. Pleskot, Warszawa 2015.

Korboński S., W imieniu Kremla, Warszawa 2017.

Lencznarowicz J., Jałta. W kręu mitów założycielskich polskiej emigracji politycznej 19441956, Kraków 2009.

Pasztor M., Spór o Triest $w$ relacjach dyplomatycznych polsko-włoskich $w$ latach 1945-1947, „Kwartalnik Historyczny” 2014, nr 2.

Wawryszuk P., Polityka władz Jugosławii wobec Kościoła katolickiego w latach 1945-1971, „Pamięć i Sprawiedliwość” 2017, nr 1.

Wituch T., Spór o Triest - wczesny epizod „zimnej wojny”, „Dzieje Najnowsze” 1997, nr 2.

Wolański M.S., Europa Środkowo-Wschodnia w myśli politycznej emigracji polskiej $w$ latach 1945-1975, Wrocław 1996.

Wolsza T., Polsko-jugostowiańskie kontakty sportowe $w$ dwudziestoleciu międzywojennym $i$ w pierwszych powojennych latach (do 1950 r.). Przyktad sportu szachowego, w: Polska i Jugostawia po II wojnie światowej, red. M. Pavlović, N. Stambolija, A. Zaćmiński, Bydgoszcz 2016, s. 127-138.

Wolsza T., Proces generała Dragoljuba Mihailovicia w świetle polskiej publicystyki emigracyjnej (1946 r.), w: Polska i Jugostawia w stosunkach międzynarodowych po II wojnie światowej, red. M. Pavlović, A. Zaćmiński, Bydgoszcz 2014, s. 195-202.

Wolsza T., Za żelazna kurtyna. Europa Środkowo-Wschodnia, Zwiazek Sowiecki i Józef Stalin $w$ opiniach polskiej emigracji politycznej $w$ Wielkiej Brytanii 1944/1945-1953, Warszawa 2005.

Zacharias M.J., Komunizm, federacja, nacjonalizmy. System władzy w Jugosławii 1943-1991. Powstanie - przeksztatcenia - rozktad, Warszawa 2004. 
Žutić N., Nadbiskup Stepinac. Ideologija i polityka 1934-1946, Beograd 2017.

Żurek P., Polacy w oddziałach czetników Dražy Mihailovicia, „Przegląd Wojskowo-Historyczny" 2018, nr 3-4.

Żurek P., Stowenia pod rzqdami Tity (1945-1980). W cieniu Jugostawii, Kraków 2017.

Bi og r a m: Tadeusz Wolsza - prof. dr hab.; zatrudniony w Instytucie Historii PAN w Warszawie i w Instytucie Nauk Politycznych Uniwersytetu Kazimierza Wielkiego w Bydgoszczy. Członek Kolegium Instytutu Pamięci Narodowej, przewodniczący Rady Muzeum II Wojny Światowej. Prowadzi badania w zakresie dziejów politycznych polskiej emigracji politycznej po 1945 r., zbrodni katyńskiej oraz historii sportu. E-mail: mwolsza@wp.pl. 